Article

\title{
Isolation, Characterization, and HPTLC-Quantification of Compounds with Anticancer Potential from Loranthus Acaciae Zucc.
}

\author{
Omar M. Noman ${ }^{1}\left(\right.$, Fahd A. Nasr ${ }^{1}{ }^{(}$, Ramzi A. Mothana $^{2, *}$, Ali S. Alqahtani $\left.{ }^{1,2}{ }^{(}\right)$, \\ Wajhul Qamar ${ }^{3,4}$, Abdullah A. Al-Mishari ${ }^{1}$, Adnan J. Al-Rehaily ${ }^{2}$, Nasir A. Siddiqui ${ }^{2} \mathbb{D}$, \\ Perwez Alam ${ }^{2}$ and Omer M. Almarfadi ${ }^{2}$
}

1 Medicinal Aromatic, and Poisonous Plants Research Center, College of Pharmacy, King Saud University, Riyadh 11451, Saudi Arabia; onoman@ksu.edu.sa (O.M.N.); fnasr@ksu.edu.sa (F.A.N.);

alalqahtani@ksu.edu.sa (A.S.A.); aalmshari@ksu.edu.sa (A.A.A.-M.)

2 Department of Pharmacognosy, College of Pharmacy, King Saud University, P.O. Box 2457, Riyadh 11451, Saudi Arabia; ajalreha@ksu.edu.sa (A.J.A.-R.); nsiddiqui@ksu.edu.sa (N.A.S.); aperwez@ksu.edu.sa (P.A.); oalmarfadi@ksu.edu.sa (O.M.A.)

3 Central Laboratory, College of Pharmacy, King Saud University, P.O. Box 2457, Riyadh 11451, Saudi Arabia; wqidris@ksu.edu.sa

4 Department of Pharmacology and Toxicology, College of Pharmacy, King Saud University, P.O. Box 2457, Riyadh 11451, Saudi Arabia

* Correspondence: rmothana@ksu.edu.sa; Tel.: +966-11-4677256 or +966-502002042; Fax: +966-11-4677245

Received: 14 July 2020; Accepted: 28 July 2020; Published: 3 August 2020

\begin{abstract}
The cytotoxic effects of the crude extract of Loranthus acaciae Zucc. and its $n$-hexane, chloroform, and $n$-butanol fractions were assessed against three cancer cell lines using the 3-(4,5-dimethylthiazol-2-yl)-2,5-diphenyl tetrazolium bromide assay. Cell apoptosis was determined using an annexin V-phycoerythrin/7-aminoactinomycin kit. We observed that the L. acaciae n-hexane extract (LAHE) could inhibit cancer cell growth, particularly of MCF7 and A549 cells. Chromatographic purification of LAHE and nuclear magnetic resonance analysis led to the identification of two compounds from this plant species, namely, betulinic acid and $\beta$-sitosterol, for the first time. Flow cytometry study suggested that betulinic acid induced cell death via apoptosis, as a distinguished marked enhancement in the early and late apoptosis of human lung (A549) and breast (MCF-7) cancer cell lines. The isolated compounds were further estimated concurrently in LAHE using a validated high-performance thin-layer chromatographic (HPTLC) method on a $10 \times 10 \mathrm{~cm}^{2} \mathrm{HPTLC}$ plate with chloroform, methanol, and glacial acetic acid $(97: 2: 1, v / v / v)$ as the mobile phase and a $\lambda_{\max }$ of $540 \mathrm{~nm}$. The amounts of betulinic acid and $\beta$-sitosterol in LAHE were 69.46 and $135.53 \mu \mathrm{g} / \mathrm{mg}$ of dried weight of extract, respectively. The excellent cytotoxic effect of LAHE could be attributed to the presence of ample amounts of betulinic acid.
\end{abstract}

Keywords: Loranthus acaciae Zucc.; isolation; betulinic acid; cancer; high-performance thin-layer chromatography; apoptosis

\section{Introduction}

Cancer is the second reason of death around the world. Approximately, 17 million individuals were diagnosed with cancer, and 9.6 million cases of deaths were reported worldwide in 2018; the most common types include lung cancer, breast cancer, prostate cancer, colorectal, and skin cancer, they account for around $40 \%$ mortality [1]. Current conventional cancer treatments put the patients 
under a lot of stress and further damage to their health. Therefore, there is a focus on using alternative treatments and therapies against cancer [2,3].

Diversity in the chemical structures of phytoconstituents from medicinal plants has always been a driving force in drug discovery [4]. Saudi Arabia encompasses $80 \%$ of the Arabian Peninsula and is home to more than 1200 plant species with great diversity and medicinal use [5]. The harsh environmental conditions of the country, including water scarcity, low-nutrient soils, and extreme temperatures, are considered positive features that confer additional chemical defenses to medicinal plants as compared with those grown under favorable conditions [6].

There are thousands of plant species that have been reported till now with significant anticancer potential [2]. Novel anticancer drugs from terrestrial plants are being continuously searched for, and several anticancer drugs have been isolated. Recently, there has been an exponential increase in the number of newly explored natural compounds that are under clinical trials [7], motivating us to explore the Saudi flora for their potential anticancer effects along with the isolation and characterization of active compounds.

Loranthus acaciae Zucc. and other species of Loranthaceae have a wide distribution in Saudi Arabia, as well as extensive histories of their application in Saudi folk medicine for the treatment of various diseases [8]. Various pharmacological activities have been identified for L. acaciae, including antihyperglycemic and antimicrobial activities $[9,10]$. Moreover, phytochemical investigations have led to the isolation and identification of phenolic compounds exhibiting free radical scavenging activity $[11,12]$. We recently reported about the antidiabetic, anti-inflammatory, and antioxidant activities, as well as isolation and identification of four flavonoid derivatives, namely, quercetin 3-O- $\beta$-D-glucopyranoside, quercetin 3-O- $\beta$-(6-O-galloyl)-glucopyranoside, (-)-catechin, and catechin 7-O-gallate, from the chloroform fraction of L. acaciae [13]. Furthermore, several other studies have demonstrated the anticancer properties of various members of the Loranthaceae family, such as Loranthus micranthus, Loranthus parasiticus, and Loranthus ferrugineus [14-16]. However, there have been no studies evaluating the cytotoxic effects of $L$. acaciae. Therefore, we aimed to evaluate the cytotoxic potential of the crude extract and different fractions of L. acaciae against various cancer cell lines and to isolate the active compounds from the most potent fraction. Furthermore, the isolated pure compounds of $L$. acaciae extract were quantitatively estimated via high-performance thin-layer chromatography (HPTLC). Several research works have revealed the HPTLC estimation of $\beta$-sitosterol in plant extracts as well as marketed herbal preparations [17-20]. Betulinic acid has been also estimated in different parts of plants, like in rhizome of Nelumbo nucifera [21], in aquatic plant Nymphoides macrospermum [22], and in the stem of Ancistrocladus heyneanus [23], by using validated HPTLC method. After exhaustive literature work, it was found that the quantitative analysis of betulinic acid and $\beta$-sitosterol has been only carried out by Anupam and Srivastav [24], in Alstonia scholaris root bark using chloroform-methanol $(99: 1 \mathrm{v} / \mathrm{v})$ as mobile phase, but there is no report found on the simultaneous quantitative HPTLC analysis of betulinic acid and $\beta$-sitosterol in L. acacia. Therefore, we planned to analyze the isolated compounds (betulinic acid and $\beta$-sitosterol) in L. acacia extract by validated HPTLC method. In addition, there is no available literature on the anticancer activity of L. acaciae. Therefore, this study may be the first report to investigate and quantify the anticancer compounds of L. acaciae hexane extract (LAHE).

\section{Materials and Methods}

\subsection{Plant Collection and Authentication}

The leaves and stems of L. acaciae were collected in 2012 during the autumn season from the southern region of Saudi Arabia. The plant material was certified by Dr. Mohammed Yusuf, Field Botanist, King Saud University (KSU, Riyadh, Saudi Arabia), Riyadh, Saudi Arabia. The voucher specimen $(15,809)$ was deposited in the herbarium of Pharmacognosy Department, College of Pharmacy, KSU. 


\subsection{Preparation of the Extracts and Fractions}

The aerial parts were dried in artificial heat at $45{ }^{\circ} \mathrm{C}$ and coarsely powdered (500 g) before extraction with ethanol $(3000 \mathrm{~mL})$ using a Soxhlet apparatus. The liquid extract was concentrated under vacuum using a rotavap to obtain $61 \mathrm{~g}$ of the crude semi-solid ethanol extract. This crude extract was further suspended in distilled water and successively partitioned with solvents of different polarities, i.e., $\mathrm{n}$-hexane, chloroform, and $n$-butanol, to produce $6.5,11$, and $20 \mathrm{~g}$ of dried fractions, respectively.

\subsection{Compound Isolation and Identification}

LAHE ( $5 \mathrm{~g})$ was separated via silica gel column chromatography $(72 \mathrm{~g}, 80 \times 3 \mathrm{~cm})$. Elution began with 3\% hexane:ethyl acetate, and the polarity was increased with ethyl acetate. After checking the thin-layer chromatography (TLC) behavior, homogenous fractions were pooled to generate seven fractions $(A-G)$. Since the anticancer activity remained in fraction $B$, fraction $B(50 \mathrm{mg})$ was further eluted with $5 \%$ hexane:ethyl acetate and rechromatographed on a normal-phase column $(7.2 \mathrm{~g}, 60 \times 1 \mathrm{~cm})$ to obtain compounds $\mathbf{1}$ and $\mathbf{2}$.

\subsection{Anticancer Activity}

\subsubsection{Determination of Cell Viability}

Cell viability was determined via the 3-(4, 5-dimethylthiazol-2-yl)-2, 5-diphenyl tetrazolium bromide assay (MTT) assay against the breast (MCF-7), lung (A549), and HepG2 (liver) cancer cell lines, which were obtained from the German Collection of Microorganisms and Cell Cultures (DSMZ, Braunschweig, Germany), and against human umbilical vein endothelial cells (HUVEC cells) 16549, which were purchased (Cat no. PCS-100-010; ATTCC, MD, USA). The assay was performed as described previously [25]. Briefly, culture plates (24-well) were seeded with $5 \times 104$ HepG2 (liver), MCF-7 (breast), or A549 (lung) cancer cells or normal human umbilical vein endothelial cells (HUVECs) in $1 \mathrm{~mL}$ of DMEM medium and allowed to attach overnight at $37^{\circ} \mathrm{C}$ in a $5 \% \mathrm{CO}_{2}$ incubator. After $24 \mathrm{~h}$, the cells were treated with different concentrations of LAHE for $48 \mathrm{~h}$. Then, $100 \mu \mathrm{L}$ of MTT ( $5 \mathrm{mg} / \mathrm{mL})$ was added to each well, and the plate was incubated at $37^{\circ} \mathrm{C}$ in $5 \% \mathrm{CO}_{2}$ for $4 \mathrm{~h}$. A solubilization solution $(0.01 \mathrm{~N} \mathrm{HCl} /$ isopropanol) was added to the wells to solubilize the formazan, and the plate was placed on a shaker for $10 \mathrm{~min}$. The absorbance at $\lambda=570 \mathrm{~nm}$ was measured on a microplate reader (BioTek, Winooski, VT, USA). The percentage viability of treated cells normalized to that of negative-control was assessed, and the $\mathrm{IC}_{50}$ (tested sample concentration required to inhibit cell growth by 50 percent) values of each tested extract or compound were calculated from the dose-response curves using the following formula:

Cell viability $(\%)=[$ optical density $(\mathrm{OD})$ of the treated sample $) /(\mathrm{OD}$ of the untreated sample $] \times 100 \%$

\subsubsection{Flow Cytometric Analysis of Cell Apoptosis}

A PE Annexin V Apoptosis Detection Kit with 7-Aminoactinomycin D (BioLegend, San Diego, CA, USA). was used to detect the induction of apoptosis after treatment with the isolated betulinic acid following the manufacturer's instructions. Briefly, both MCF-7 and A549 cells were seeded into 12-well tissue culture plates at a density of $5 \times 10^{4}$ cells/well for $24 \mathrm{~h}$ at $37^{\circ} \mathrm{C}$ for adherence, followed by treatment with betulinic acid at its $\mathrm{IC}_{50}$ value $(17 \mu \mathrm{g} / \mathrm{mL})$ for $24 \mathrm{~h}$. Cells were collected, washed twice in cold PBS, and resuspended in kit-specific binding buffer. They were then incubated in the dark with $5 \mu \mathrm{L}$ of annexin V-phycoerythrin (PE) and $5 \mu \mathrm{L}$ of 7-aminoactinomycin (7-AAD) for 15 min at room temperature. After the incubation period, $400 \mu \mathrm{L}$ of annexin-binding buffer was added, and the samples were immediately analyzed using a flow cytometer (Beckman Coulter, Brea, CA, USA) with three replicates. 


\subsection{Development of the HPTLC Procedure to Determine Betulinic Acid and $\beta$-Sitosterol in LAHE}

Betulinic acid and $\beta$-sitosterol procured from Sigma Aldrich (St Louis, MO, USA) were used for the quantitative analysis in LAHE using validated HPTLC method and carried out on a $10 \times 10 \mathrm{~cm}^{2}$ NP-HPTLC plate (Merck, Darmstadt, Germany). Stock solutions of betulinic acid and $\beta$-sitosterol standards $(1 \mathrm{mg} / \mathrm{mL})$ were prepared in chloroform and diluted further with chloroform to obtain seven different dilutions (20-140 $\mu \mathrm{g} / \mathrm{mL})$. The prepared dilutions of betulinic acid and $\beta$-sitosterol, as well as LAHE $(5 \mu \mathrm{L})$, were applied to the HPTLC plate using a microliter syringe attached to an Automatic TLC Sampler-4 (CAMAG, Switzerland) with 6-mm band size at a speed of $160 \mathrm{~nL} / \mathrm{s}$ to obtain a linearity range of $200-1400 \mathrm{ng} / \mathrm{band}$. The loaded TLC plate was then developed in a $20 \times 10 \mathrm{~cm}^{2}$ pre-saturated glass chamber under controlled temperature $\left(25^{\circ} \mathrm{C} \pm 2{ }^{\circ} \mathrm{C}\right)$ and humidity $(60 \% \pm 5 \%)$. The developed TLC plate was visualized using a spray reagent (vanillin/HCl, Noida, India) to visualize the spots of the standards and phytoconstituents present in the samples (extract fractions). Quantitative analysis was conducted at an optimized UV wavelength of $540 \mathrm{~nm}$ in the absorbance mode. The proposed chromatographic method was validated by considering the following parameters suggested in the ICH guidelines [26]: limit of detection (LOD), limit of quantification (LOQ), precision, recovery (as accuracy), and robustness.

\subsection{Statistical Analysis}

The data collected were expressed as mean \pm SD. Each sample was analyzed in triplicate, and differences versus the control were considered statistically significant at $p<0.05$. All statistical charts were managed using Origin Lab software (version 8, Northampton, MA, USA).

\section{Results and Discussion}

\subsection{Isolated Compounds from $L A H E$}

\section{Compound 1}

Compound 1 (Figure 1) was isolated as white crystals. Its mass spectral data suggested a molecular formula of $\mathrm{C}_{30} \mathrm{H}_{48} \mathrm{O}_{3}$. The ${ }^{1} \mathrm{H}$ NMR spectrum revealed signals for five tertiary methyl $(\delta \mathrm{H}: 0.64,0.76$, $0.86,0.87$, and 0.93$)$, one vinyl methyl $(\delta \mathrm{H}: 1.80(\mathrm{~d}, J=0.5 \mathrm{~Hz}))$, one secondary carbinol $(\delta \mathrm{H}: 3.34$ $(\mathrm{dd}, J=9.5$ and $6.0 \mathrm{~Hz}))$ and $(\delta \mathrm{H}: 2.95(\mathrm{ddd}, J=9.0,6.0$, and $0.5 \mathrm{~Hz}))$, and one exomethylene group $(\delta \mathrm{H}: 4.55(1 \mathrm{H}, \mathrm{d}, J=0.4 \mathrm{~Hz}))$ and $(\delta \mathrm{H}: 4.68(1 \mathrm{H}, \mathrm{d}, J=0.4 \mathrm{~Hz}))$. The ${ }^{13} \mathrm{C}$ NMR spectrum revealed six methyl groups (8C: 28.5 (C-23), 16.09 (C-24), 15.96 (C-25), 15.8 (C-26), 14.5 (C-27), and 19.4 (C-30)), one exomethylene group ( $\delta \mathrm{C}: 150.0(\mathrm{C}-30), 108.8$ (C-29)), one secondary hydroxyl-bearing carbon $(\delta \mathrm{C}: 79.0$ $(\mathrm{C}-3)$ ), and one carboxyl group ( $\delta \mathrm{C}: 177.4(\mathrm{C}-28)$ ) in addition to ten methylene, five methine, and five quaternary carbons. After the complete interpretation of the NMR data based on COSY, HSQC, and HMBC experiments, compound 1 was determined to be betulinic acid (Table 1).

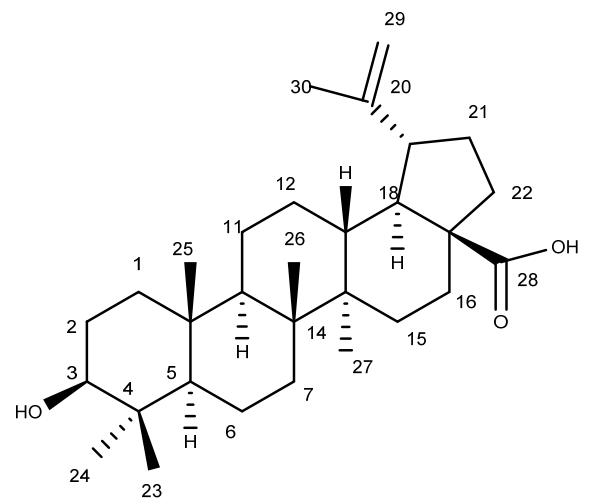

1

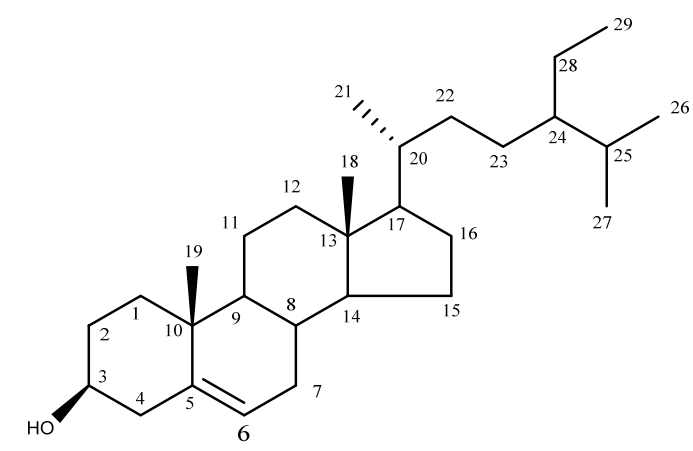

2

Figure 1. Isolated compounds 1 (betulinic acid) and 2 ( $\beta$-sitosterol) from L. acacia. 
Table 1. ${ }^{1} \mathrm{H}$ and ${ }^{13} \mathrm{C}-\mathrm{NMR}$ data for compounds 1 and $2\left(\mathrm{CD}_{3} \mathrm{OD}\right)$.

\begin{tabular}{|c|c|c|c|c|}
\hline \multirow{2}{*}{ Position } & \multicolumn{2}{|l|}{ Compound 1} & \multicolumn{2}{|c|}{ Compound 2} \\
\hline & \multicolumn{2}{|c|}{$\delta_{\mathrm{H}}(J$ in $\mathrm{Hz}) \delta \mathrm{c} p \mathrm{pm}$} & \multicolumn{2}{|c|}{$\delta_{H}(J$ in $\mathrm{Hz}) \delta \mathrm{c}$ ppm } \\
\hline 1 & & 39.4 & & 37.5 \\
\hline 2 & & 28.1 & & 31.9 \\
\hline 3 & $3.34(\mathrm{dd}, J=9.5,6.0)$ & 76.90 & $\begin{array}{c}3.53(\mathrm{dd}, J=4.5,4.2 \\
3.8)\end{array}$ & 72.0 \\
\hline 4 & & 39.6 & & 42.5 \\
\hline 5 & $0.70 *$ & 55.55 & $5.36(\mathrm{t}, J=6.4)$ & 140.9 \\
\hline 6 & & 18.6 & & 121.9 \\
\hline 7 & & 34.7 & & 32.1 \\
\hline 8 & & 40.38 & & 32.1 \\
\hline 9 & & 50.6 & & 50.3 \\
\hline 10 & & 37.6 & & 36.7 \\
\hline 11 & & 20.58 & & 21.3 \\
\hline 12 & & 25.9 & & 39.9 \\
\hline 13 & & 38.6 & & 42.6 \\
\hline 14 & & 42.13 & & 56.9 \\
\hline 15 & & 30.22 & & 26.3 \\
\hline 16 & & 31.8 & & 28.5 \\
\hline 17 & & 55.02 & & 56.3 \\
\hline 18 & & 46.75 & & 36.3 \\
\hline 19 & $2.95(\mathrm{t}, J=7)$ & 48.6 & $0.93(\mathrm{~d}, J=6.5)$ & 19.2 \\
\hline 20 & & 150.46 & & 34.2 \\
\hline 21 & & 30.22 & & 26.3 \\
\hline 22 & & 38.3 & & 46.1 \\
\hline 23 & $0.87 *$ & 28.5 & & 23.3 \\
\hline 24 & $0.64 *$ & 16.09 & $0.84(\mathrm{t}, J=7.2)$ & 12.2 \\
\hline 25 & $0.76^{*}$ & 15.96 & & 29.4 \\
\hline 26 & $0.87 *$ & 15.8 & $0.83(\mathrm{~d}, J=6.4)$ & 20.1 \\
\hline 27 & $0.93 *$ & 14.5 & $0.81(\mathrm{~d}, J=6.4)$ & 19.6 \\
\hline 28 & & 177.4 & $0.68 \mathrm{~s}$ & 19.0 \\
\hline $29 a$ & $4.55(\mathrm{~d}, J=0.4)$ & 109.8 & $1.01 \mathrm{~s}$ & 12.0 \\
\hline $29 b$ & $4.68(\mathrm{~d}, J=0.4)$ & & & \\
\hline 30 & $1.80(\mathrm{~d}, J=0.5)$ & 19.4 & - & - \\
\hline
\end{tabular}

*: Overlapping.

\section{Compound 2}

Compound 2 (Figure 1) was also isolated as a white powder. Its mass spectral data suggested a molecular formula of $\mathrm{C}_{29} \mathrm{H}_{50} \mathrm{O}$. The ${ }^{1} \mathrm{H}$ NMR spectrum of 2 revealed the presence of six methyl signals that appeared as two methyl singlets at $\delta 0.69$ and 1.01 ; three methyl doublets at $\delta 0.81,0.83$, and 0.93 ; and a methyl triplet at $\delta 0.85$. The ${ }^{1} \mathrm{H}$ NMR spectrum of 2 also displayed one olefinic proton at $\delta 5.36$ and a proton corresponding to the proton connected to the C-3 hydroxyl group, which appeared as a triplet of doublets at $\delta 3.53$. The ${ }^{13} \mathrm{C}$ NMR together with COSY, HMQC, and HMBC revealed 29 carbon signals, including 6 methyl, 11 methylene, 10 methane, and 3 quaternary carbons. A comparison of the ${ }^{1} \mathrm{H}-\mathrm{NMR}$ and ${ }^{13} \mathrm{C}-\mathrm{NMR}$ results of 2 with published data indicated that the compound was $\beta$-sitosterol. This represents the isolation of this compound from L. acaciae for the first time. However, it was previously isolated from other plant species, including Plicosepalus curviflorus [27].

\subsection{Cytotoxic Activity}

The potential anticancer effect of L. acaciae was tested against selected human malignant cell lines, namely, A549 (lung), HepG2 (liver), and MCF-7 cells (breast), as well as against HUVECs. Both the crude extract and its fractions exerted selective dose-dependent cytotoxic effects on both tumor cells 
and HUVECs. According to the $\mathrm{IC}_{50}$ values, these extracts exhibited considerable cytotoxic activity against MCF-7 and A549 cells (Table 2).

Table 2. $\mathrm{IC}_{50}$ values for the L. acacia crude extract and fractions.

\begin{tabular}{ccccccc}
\hline \multirow{2}{*}{ Cell Lines } & \multicolumn{5}{c}{$\mathrm{IC}_{\mathbf{5 0}}(\boldsymbol{\mu g} / \mathrm{mL})$} \\
\cline { 2 - 7 } & Crude ex. & Hex ex. & $\mathbf{C H C l}_{\mathbf{3}}$ ex. & ButOH ex. & Betulinic Acid $(\mu \mathrm{M})$ & Cisplatin $(\boldsymbol{\mu M})$ \\
\hline A549 & $180 \pm 4.1$ & $62 \pm 2.1$ & $63.5 \pm 1.5$ & $99.5 \pm 1.2$ & $37.22 \pm 1.4$ & $6.9 \pm 0.5$ \\
HepG2 & $284 \pm 3.2$ & $94.5 \pm 2.5$ & $154 \pm 2.6$ & $166 \pm 1.9$ & $43.8 \pm 1.6$ & $8.3 \pm 0.3$ \\
MCF-7 & $280 \pm 2.1$ & $58.9 \pm 2$ & $88 \pm 3.4$ & $94 \pm 2.7$ & $37.8 \pm 1.2$ & $5.9 \pm 0.4$ \\
HUVEC & $289 \pm 3.1$ & $99.3 \pm 2.5$ & $105 \pm 1.1$ & $118 \pm 1.5$ & $80.79 \pm 2.2$ & $20.2 \pm 0.5$ \\
\hline
\end{tabular}

$\mathrm{IC}_{50}$ : tested sample concentration required to inhibit cell growth by 50 percent, $\mathrm{Hex}$ ex.: hexane extract, $\mathrm{CHCl}_{3}$ ex.: chloroform extract, ButOH ex.: butanol extract.

Compared with other fractions, LAHE exhibited highly selective anticancer activity against all tested cancer cells (Figure 2A); therefore, it was selected for further studies. Betulinic acid, which was isolated from LAHE, displayed strong cytotoxic activity (Figure 2B), whereas $\beta$-sitosterol exhibited weak activity (data not shown).

(A)

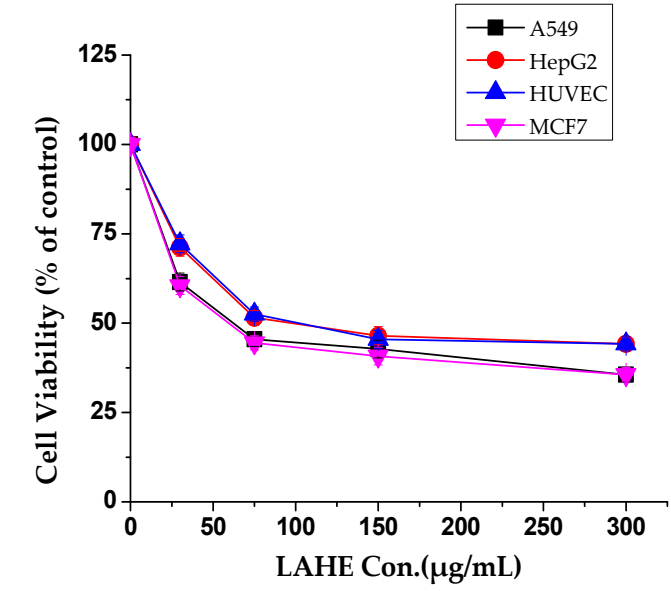

(B)

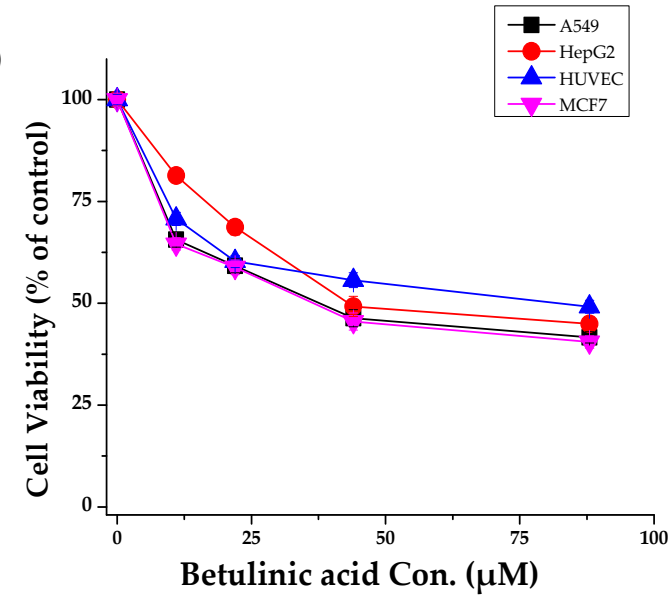

(C)

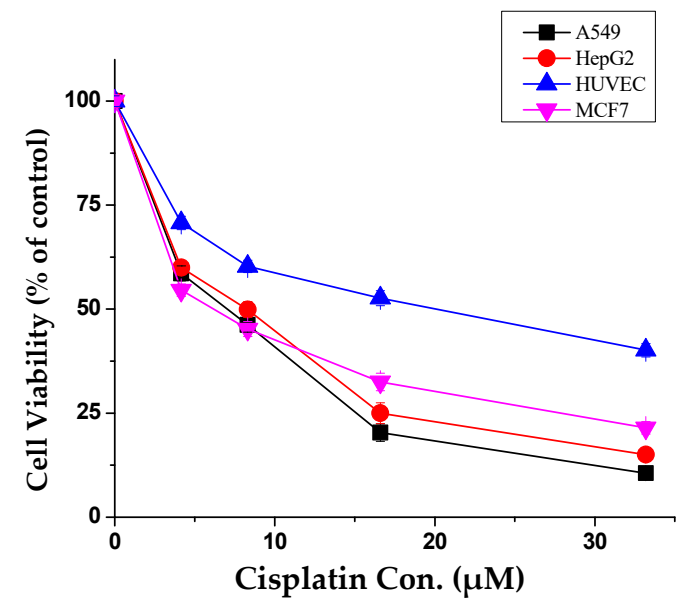

Figure 2. Tumor and normal cells dose-response curves for hexane fraction (LAHE) and betulinic acid. (A) Dose-dependent curves of n-hexane fraction, (B) Betulinic acid, and (C) Cisplatin (positive control). Cells were cultured in 24-well plates and treated with different concentrations $(10-300 \mu \mathrm{g} / \mathrm{mL})$ for $48 \mathrm{~h}$. Cell viability was determined by MTT assay. Data were analyzed using Origin Pro 8 software. LAHE, L. acaciae $\mathrm{n}$-hexane extract. 
In chemoprevention studies, bioactive compounds that can induce apoptosis rather than necrosis in cancer cells are more desirable. Therefore, the induction of apoptosis was investigated after treatment with betulinic acid. Phosphatidylserine exposure in the cell surface is a classic feature of cells undergoing apoptosis [28]. Using flow cytometry, this method can identify apoptosis at an earlier stage as compared with assays based on nuclear changes, such as DNA fragmentation [29].

In this study, a PE annexin V apoptosis detection kit with 7-AAD was used. In the kit, annexin $\mathrm{V}$, which is conjugated to the fluorochrome PE, has a high affinity for phosphatidylserine, which is redistributed from the inner to the outer leaflet of the plasma membrane during early apoptotic events. Conversely, 7-AAD detects dead cells by binding to cellular DNA inside the cell. As shown in Figure 3, following the treatment of A549 and MCF-7 with isolated betulinic acid at its IC $\mathrm{C}_{50}$ value $(17 \mu \mathrm{g} / \mathrm{mL})$, a noticeable increase in the percentage of apoptotic cells was reported. The percentages of surviving, early apoptotic, late apoptotic, and necrotic cells in A549 cells were 58.87\% $\pm 0.6 \%, 9.31 \% \pm 0.4 \%$, $15.21 \% \pm 0.3 \%$, and $15.16 \% \pm 0.6 \%$ and those in MCF-7 cells were $48.29 \% \pm 0.4 \%, 11.87 \% \pm 0.3 \%$, $23.4 \% \pm 0.56 \%$, and $15.3 \% \pm 0.4 \%$, respectively, compared to in the untreated cells (Figure 3B).

(A)
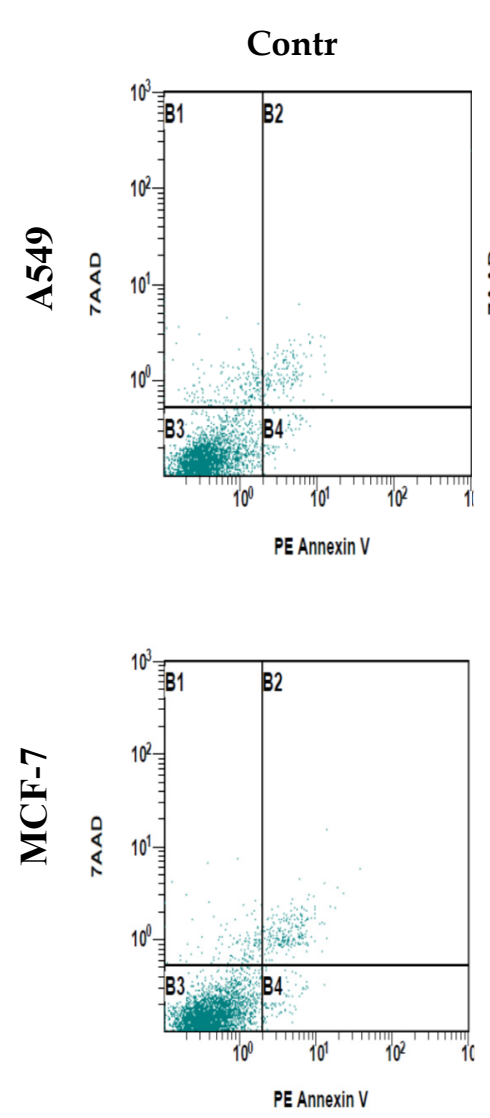

Treated

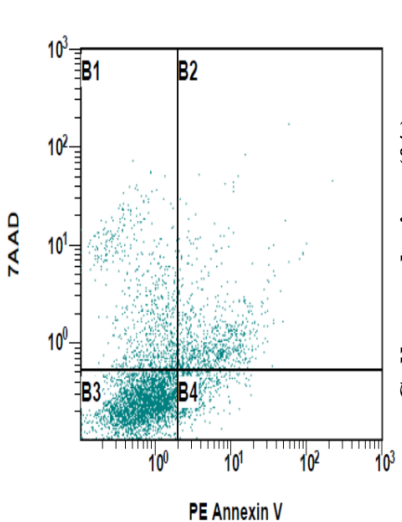

PE Annexin V

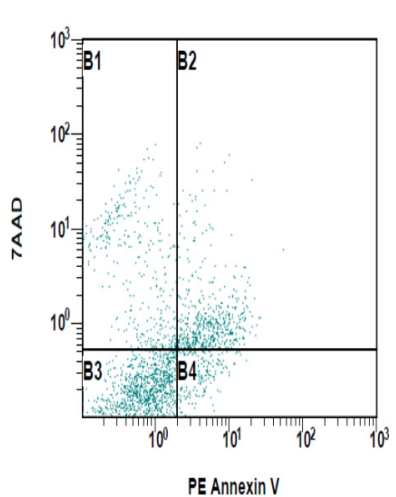

(B)
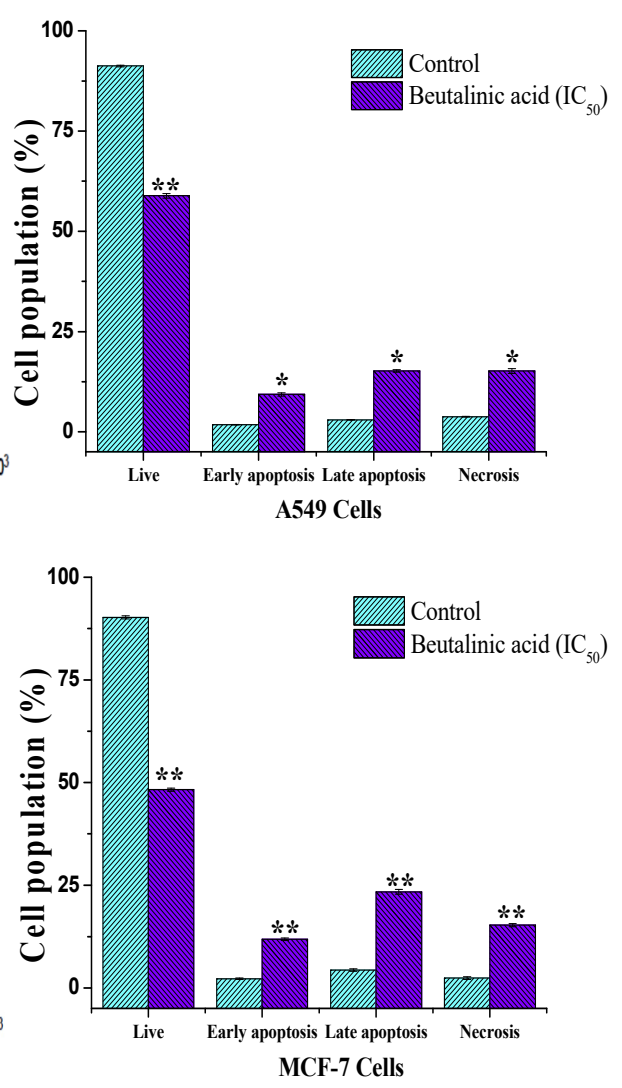

Figure 3. Apoptosis induction in MCF-7 and A549 cells treated with isolated betulinic acid. Cells were treated at $\mathrm{IC}_{50}$ for $24 \mathrm{~h}$ and stained with V-Phycoerythrin Annexin V and 7-Aminoactinomycin D dye, thereafter analyzed by flow cytometry. (A) The upper right and left quadrants (B1 and B2) contain necrotic and late apoptotic cells, while the lower left quadrants (B3 and B4) represent the live and the early apoptotic cells, respectively. (B) Bar graph of live, apoptosis, and necrosis cells using flow cytometry. ${ }^{*} p<0.05,{ }^{* *} p<0.01$ vs. control.

Betulinic acid is a pentacyclic triterpenoid that is widely distributed in the plant kingdom. It possesses various biological activities, including anticancer activity against different cancer cell lines [30]. After exploring its role as an anticancer compound, the focus has shifted toward elucidating 
its mechanism of action. Various studies have shown that it induces apoptosis in several cell lines, including human neuroblastoma [31], leukemia [32], and different adenocarcinoma cell lines (i.e., breast, lung, and colon cancer cells) [33]. We reported the isolation of betulinic acid from L. acaciae for the first time and demonstrated its excellent anticancer activity via the inhibition of cell viability and induction of apoptosis.

\subsection{Concurrent Analysis of Betulinic Acid and $\beta$-Sitosterol in LAHE by a Validated HPTLC Method}

By testing various compositions of different solvents, the most suitable mobile phase for betulinic acid and $\beta$-sitosterol analysis in LAHE was a mixture of chloroform, methanol, and glacial acetic acid [97:2:1 $(v / v / v)]$. Intense and sharp peaks of betulinic acid and $\beta$-sitosterol were observed at Rfs (retention factors) of $0.31 \pm 0.001$ and $0.41 \pm 0.001$, respectively (Figure 4A). This approach was found to clearly separate the standards of betulinic acid and $\beta$-sitosterol and isolated compounds of LAHE (Figure 4B). The authentication of bands was conducted by matching (overlaying) the spectra of the extract with those of betulinic acid and $\beta$-sitosterol (Figure 4C).
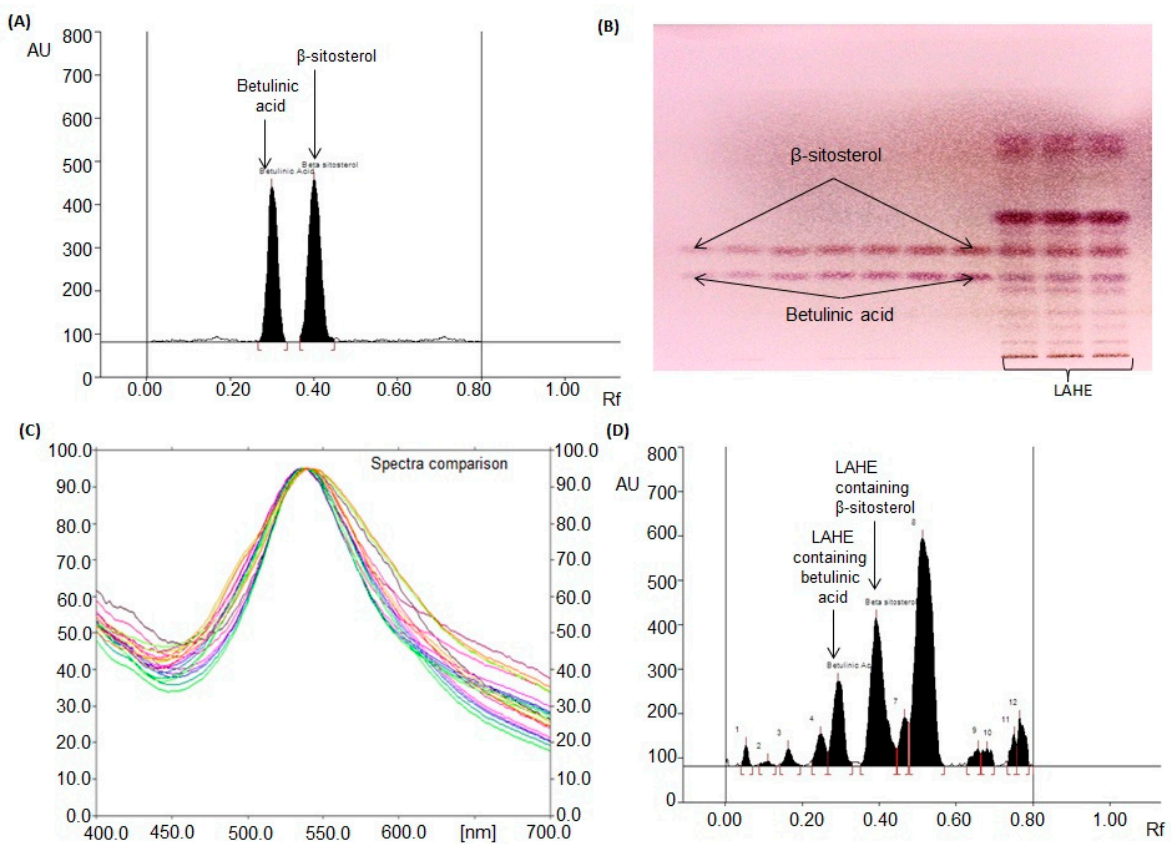

Figure 4. Chromatogram of betulinic acid and $\beta$-sitosterol estimation in L. acacia hexane extract (LAHE). [Mobile phase: chloroform: methanol: glacial acetic acid (97:2:1, v/v/v)]. (A) Chromatogram of standards betulinic acid $(\mathrm{Rf}$ (retention factor) $=0.31 \pm 0.001)$ and $\beta$-sitosterol $\left(\mathrm{R}_{\mathrm{f}}=0.41 \pm 0.001\right)$ at $540 \mathrm{~nm}$;

(B) Pictogram of derivatized TLC plate in day light; (C) spectral comparison of all tracks at $540 \mathrm{~nm}$;

(D) Chromatogram of L. acacia hexane fraction (betulinic acid, spot $5, \mathrm{R}_{\mathrm{f}}=0.31 ; \beta$-sitosterol, spot 6, $\mathrm{R}_{\mathrm{f}}=0.41$ ).

The developed procedure was approved by the ICH guideline of 2005 to evaluate LOD, LOQ, precision, accuracy, and robustness. It was discovered that the created technique was completely selective with good baseline resolution. In the linearity range of 200-1400 ng/spot, the regression equations and correlation coefficients were $Y=5.206 X+117.77$ and $Y=4.514 X+1039.7$ and 0.996 and 0.9979 for betulinic acid and $\beta$-sitosterol, respectively. LOD and LOQ were 34.51 and $104.57 \mathrm{ng}$ for betulinic acid and 40.95 and $124.11 \mathrm{ng}$ for $\beta$-sitosterol, respectively (Table 3 ). The results of the recovery analysis of the developed procedure are presented in Table 4. 
Table 3. Rf, linear regression data for the calibration curve of betulinic acid and $\beta$-sitosterol $(n=6)$.

\begin{tabular}{ccc}
\hline Parameters & Betulinic Acid & $\beta$-Sitosterol \\
\hline Linearity range (ng/spot) & $200-1400$ & $200-1400$ \\
Regression equation & $\mathrm{Y}=5.206 \mathrm{X}+117.77$ & $\mathrm{Y}=4.514 \mathrm{X}+1039.7$ \\
Correlation $\left(r^{2}\right)$ coefficient & 0.996 & 0.9979 \\
Slope \pm SD & $5.206 \pm 0.05$ & $4.514 \pm 0.056$ \\
Intercept \pm SD & $117.77 \pm 8.60$ & $1039.7 \pm 26.45$ \\
Standard error of slope & 0.022 & 0.022 \\
Standard error of intercept & 3.51 & 10.79 \\
Rf & $0.31 \pm 0.001$ & $0.41 \pm 0.001$ \\
LOD $(\mathrm{ng})$ & 34.51 & 40.95 \\
LOQ $(\mathrm{ng})$ & 104.57 & 124.11 \\
\hline
\end{tabular}

Rf: retention factor, LOD (Limit of detection): the smallest amount or concentration of analyte in the test sample that can be reliably distinguished from zero, LOQ: (limit of quantitation): the lowest concentration of analyte that can be determined with an acceptable repeatability and trueness.

Table 4. Recovery as accuracy studies of the proposed HPTLC method $(n=6)$.

\begin{tabular}{cccccccc}
\hline $\begin{array}{c}\text { Percent (\%) of } \\
\text { Betulinic Acid and } \\
\beta \text {-Sitosterol Added } \\
\text { to Analyte }\end{array}$ & $\begin{array}{c}\text { Theoretical } \\
\text { Concentration of } \\
\text { Betulinic Acid and } \\
\beta \text {-Sitosterol } \\
\text { (ng/Band) }\end{array}$ & Concentration Found (ng/Band) \pm SD & & \%RSD & & \%Recovery \\
\hline & & Betulinic Acid & $\beta$-Sitosterol & Betulinic Acid & $\beta$-Sitosterol & Betulinic Acid & $\beta$-Sitosterol \\
\hline 0 & 400 & $395.43 \pm 5.13$ & $395.50 \pm 4.17$ & 1.29 & 1.05 & 98.85 & 98.87 \\
100 & 600 & $593.64 \pm 6.91$ & $596.41 \pm 6.11$ & 1.16 & 1.02 & 98.94 & 99.40 \\
150 & 800 & $797.67 \pm 7.83$ & $793.95 \pm 8.42$ & 0.98 & 1.06 & 99.71 & 99.24 \\
\hline
\end{tabular}

HPTLC: High-performance thin-layer chromatography, RSD: relative standard deviations.

The recoveries and relative standard deviations (RSDs, \%) were $98.85-99.71 \%$ and $0.932-1.29 \%$ for betulinic acid and $98.8-99.40 \%$ and $0.95-1.06 \%$ for $\beta$-sitosterol, respectively. The intra- and inter-day precisions for the developed technique are displayed in Table 5.

Table 5. Precision of the proposed HPTLC method $(n=6)$.

\begin{tabular}{|c|c|c|c|c|c|c|c|c|}
\hline \multirow{3}{*}{$\begin{array}{l}\text { Conc. of Standard } \\
\text { Added (ng/Band) }\end{array}$} & \multicolumn{4}{|c|}{ Betulinic Acid } & \multicolumn{4}{|c|}{$\beta$-Sitosterol } \\
\hline & \multicolumn{2}{|c|}{ Intra-Day Precision } & \multicolumn{2}{|c|}{ Inter-Pay Precision } & \multicolumn{2}{|c|}{ Intra-Day Precision } & \multicolumn{2}{|c|}{ Inter-Day Precision } \\
\hline & $\begin{array}{l}\text { Average Conc. } \\
\text { Found } \pm \text { SD }\end{array}$ & $\%$ RSD & $\begin{array}{l}\text { Average Conc. } \\
\text { Found } \pm \text { SD }\end{array}$ & $\%$ RSD & $\begin{array}{l}\text { Average Conc. } \\
\text { Found } \pm \text { SD }\end{array}$ & $\%$ RSD & $\begin{array}{l}\text { Average Conc. } \\
\text { Found } \pm \text { SD }\end{array}$ & $\%$ RSD \\
\hline 400 & $397.13 \pm 5.17$ & 1.30 & $393.28 \pm 5.12$ & 1.29 & $397.14 \pm 4.69$ & 1.18 & $392.71 \pm 4.57$ & 1.16 \\
\hline 600 & $595.31 \pm 6.91$ & 1.16 & $593.39 \pm 6.87$ & 1.15 & $595.58 \pm 6.17$ & 1.03 & $591.15 \pm 6.11$ & 1.03 \\
\hline 800 & $795.50 \pm 8.72$ & 1.09 & $791.66 \pm 8.68$ & 1.08 & $792.84 \pm 8.05$ & 1.01 & $790.62 \pm 7.87$ & 0.99 \\
\hline
\end{tabular}

The RSDs for intra- and inter-day precisions $(\mathrm{n}=6)$ were $1.09-1.30 \%$ and $1.08-1.29 \%$ for betulinic acid and $1.01-1.18 \%$ and $0.99-1.16 \%$ for $\beta$-sitosterol, respectively, demonstrating the high accuracy of the developed technique. To check the validity of the developed procedure, small but intentional changes (in mobile phase composition, saturation time, and mobile phase volume) were applied; the gathered data are presented in Table 6. The low values of SD and RSD illustrate that the developed HPTLC procedure is durable. 
Table 6. Robustness of the proposed HPTLC method $(n=6)$.

\begin{tabular}{ccccc}
\hline \multirow{2}{*}{ Optimization Condition } & \multicolumn{2}{c}{ Betulinic Acid (400 ng/Band) } & \multicolumn{2}{c}{$\beta$-Sitosterol (400 ng/Band) } \\
\cline { 2 - 5 } & SD & \%RSD & SD & \%RSD \\
\hline $\begin{array}{c}\text { Mobile phase composition; } \\
\text { (Chloroform: methanol: acetic acid) }\end{array}$ & & & & \\
\hline (97: $2: 1)$ & 4.87 & 1.22 & 4.37 & 1.10 \\
$(96.5:$ 2.5: 1$)$ & 4.81 & 1.21 & 4.31 & 1.08 \\
(97.5: $1.5: 1)$ & 4.79 & 1.20 & 4.28 & 1.07 \\
\hline Mobile phase volume & & & & \\
(for saturation) & & & & 1.11 \\
\hline$(18 \mathrm{~mL})$ & 4.59 & 1.16 & 4.41 & 1.09 \\
$(20 \mathrm{~mL})$ & 4.56 & 1.15 & 4.35 & \\
$(22 \mathrm{~mL})$ & 4.55 & 1.15 & 4.32 & 1.03 \\
\hline Duration of saturation & & & & 1.02 \\
\hline$(10 \mathrm{~min})$ & 4.77 & 1.20 & 4.13 & 1.01 \\
\hline
\end{tabular}

RSD: relative standard deviations, SD: standard deviations.

The validated HPTLC method was applied to analyze betulinic acid and $\beta$-sitosterol concurrently in LAHE (Figure 4D). The amounts of betulinic acid and $\beta$-sitosterol in LAHE were estimated to be 69.46 and $135.53 \mu \mathrm{g} / \mathrm{mg}$ of dried weight of extract, respectively. The presence of betulinic acid at high levels (as evaluated by the HPTLC method) in LAHE validated its excellent anticancer activity. HPTLC has become a valuable and effective tool for the estimation of botanical materials. It offers a better resolution for phytoconstituents and has high efficiency and cost-effectiveness. The developed chromatographic method has gained popularity in the pharmaceutical and cosmetic industries for evaluating the quality of raw materials as well as finished goods. There are several genuine reasons for its increasing adoption, such as the requirement of smaller amounts of mobile phase and standard compounds and short analysis time. Moreover, flexibility concerning solvent systems, scanning wavelengths, and multiple-sample analysis in a single run are peculiar features of this technique [34-38].

\section{Conclusions}

In conclusion, we observed that LAHE exhibited potential cytotoxic effects against various cancer cell lines. Betulinic acid obtained from the bioactive hexane fraction proved to be a potent anticancer compound, whereas $\beta$-sitosterol was less active. Betulinic acid, which was isolated from L. acaciae for the first time, exerted its anticancer effects by inhibiting cell viability and inducing apoptosis. The presence of betulinic acid in LAHE at suitable levels (as evaluated by HPTLC) also supported the excellent anticancer activity of LAHE. This is the first report on the isolation and identification of betulinic acid and $\beta$-sitosterol from the aerial parts of $L$. acaciae. The established chromatographic method can be applied for the concurrent analysis of betulinic acid and $\beta$-sitosterol in any plant species or marketed herbal formulations containing these two compounds.

Author Contributions: R.A.M. designed the study and wrote the manuscript; O.M.N., O.M.A., and A.S.A. did the extraction and isolation of the compounds; R.A.M., A.J.A.-R., and N.A.S. carried out the structure elucidation; F.A.N., W.Q., and A.A.A.-M. carried out the cytotoxicity study and flow cytometry studies; P.A. and O.M.N. performed HPTLC quantification; A.J.R. collected the plant. All authors have read and agreed to the published version of the manuscript.

Funding: This research was funded by DSR (Deanship of Scientific Research) at King Saud University through the research group project No. (RG-1441-073). 
Acknowledgments: The authors extend their appreciation to the Deanship of Scientific Research at King Saud University for funding the work through the research group project No. RG-1441-073. In addition, the authors thank the Deanship of Scientific Research and RSSU at King Saud University for their technical support.

Conflicts of Interest: The authors declare no conflict of interest.

\section{References}

1. Yar, M.S.; Haider, K.; Gohel, V.; Siddiqui, N.A.; Kamal, A. Synthetic lethality on drug discovery: An update on cancer therapy. Expert Opin. Drug Discov. 2020, 15, 823-832. [CrossRef] [PubMed]

2. Mukherjee, A.K.; Basu, S.; Sarkar, N.; Ghosh, A.C. Advances in cancer therapy with plant based natural products. Curr. Med. Chem. 2001, 8, 1467-1486. [CrossRef] [PubMed]

3. Butler, M.S. The role of natural product chemistry in drug discovery. J. Nat. Prod. 2004, 67, 2141-2153. [CrossRef] [PubMed]

4. Vuorelaa, P.; Leinonenb, M.; Saikkuc, P.; Tammelaa, P.; Rauhad, J.P.; Wennberge, T.; Vuorela, H. Natural products in the process of finding new drug candidates. Curr. Med. Chem. 2004, 11, 1375-1389. [CrossRef]

5. Rahman, M.A.; Mossa, J.S.; Al-Said, M.S.; Al-Yahya, M.A. Medicinal plant diversity in the flora of Saudi Arabia 1: A report on seven plant families. Fitoterapia 2004, 75, 149-161. [CrossRef]

6. Harlev, E.; Nevo, E.; Lansky, E.P.; Lansky, S.; Bishayee, A. Anticancer attributes of desert plants: A review. Anticancer Drugs 2012, 23, 255-271. [CrossRef]

7. Lichota, A.; Gwozdzinski, K. Anticancer Activity of Natural Compounds from Plant and Marine Environment. Int. J. Mol. Sci. 2018, 19, 3533. [CrossRef]

8. Waly, N.M.; El Din, A.A.; Jrais, R.N. Botanical and Biological studies of six parasitic species of family Loranthaceae growing in Kingdom of Saudi Arabia. Int. J. Environ. Sci. 2012, 4, 196-205.

9. Elegami, A.A.; Elnima, E.I.; Muddathir, A.K.; Omer, M.E. Antimicrobial activity of Plicosepalus acaciae. Fitoterapia 2001, 72, 431-434. [CrossRef]

10. Aldawsari, H.M.; Hanafy, A.; Labib, G.S.; Badr, J.M. Antihyperglycemic activities of extracts of the mistletoes Plicosepalus acaciae and P. curviflorus in comparison to their solid lipid nanoparticle suspension formulations. Z. Nat. C 2014, 69, 391-398. [CrossRef]

11. Badr, J.M.; Shaala, L.A.; Youssef, D.T.A. Loranthin: A new polyhydroxylated flavanocoumarin from Plicosepalus acacia with significant free radical scavenging and antimicrobial activity. Phytochem. Lett. 2013, 6, 113-117. [CrossRef]

12. Sadik, G.; Islam, R.; Rahman, M.M.; Khondkar, P.; Rashid, M.A.; Sarker, S.D. Antimicrobial and cytotoxic constituents of Loranthus globosus. Fitoterapia 2003, 74, 308-311. [CrossRef]

13. Noman, O.M.; Mothana, R.A.; Al-Rehaily, A.J.; Al Qahtani, A.S.; Nasr, F.A.; Khaled, J.M.; Alajmi, M.F.; Al-Said, M.S. Phytochemical analysis and anti-diabetic, anti-inflammatory and antioxidant activities of Loranthus acaciae Zucc. Grown in Saudi Arabia. Saudi Pharm. J. 2019, 27, 724-730. [CrossRef] [PubMed]

14. Zorofchian Moghadamtousi, S.; Hajrezaei, M.; Abdul Kadir, H.; Zandi, K. Loranthus micranthus Linn.: Biological Activities and Phytochemistry. Evid. Based Complement. Altern. Med. eCAM 2013, 2013, 273712.

15. Moghadamtousi, S.Z.; Kamarudin, M.N.; Chan, C.K.; Goh, B.H.; Kadir, H.A. Phytochemistry and biology of Loranthus parasiticus Merr, a commonly used herbal medicine. Am. J. Chin. Med. 2014, 42, 23-35. [CrossRef]

16. Ameer, O.Z.; Salman, I.M.; Quek, K.J.; Asmawi, M.Z. Loranthus ferrugineus: A Mistletoe from Traditional Uses to Laboratory Bench. J Pharmacopunct. 2015, 18, 7-18. [CrossRef]

17. Charde, M.; Chakolkar, M.; Welankiwar, A.; Keshwar, U.; Shrikande, B. Development of validated HPTLC method for the estimation of betasitosterol in marketed herbal fromulation of muscle and joint HRX pain relieving oil. Int. J. Phytopharm. 2014, 4, 70-74.

18. Ahmad, H.; Sehgal, S.; Mishra, A.; Gupta, R.; Saraf, S.A. TLC Detection of $\beta$-sitosterol in Michelia champaca L. Leaves and Stem Bark and it's Determination by HPTLC. Pharmacogn. J. 2012, 4, 45-55. [CrossRef]

19. Al-Massarani, S.M.; El Gamal, A.A.; Alam, P.; Al-Sheddi, E.S.; Al-Oqail, M.M.; Farshori, N.N. Isolation, biological evaluation and validated HPTLC-quantification of the marker constituent of the edible Saudi plant Sisymbrium irio L. Saudi Pharm. J. 2017, 25, 750-759. [CrossRef]

20. Mallick, S.S.; Dighe, V.V. Detection and Estimation of alpha-Amyrin, beta-Sitosterol, Lupeol, and n-Triacontane in Two Medicinal Plants by High Performance Thin Layer Chromatography. Adv. Chem. 2014, 2014, 143948. 
21. Mukherjee, D.; Kumar, N.S.; Khatua, T.; Mukherjee, P.K. Rapid validated HPTLC method for estimation of betulinic acid in Nelumbo nucifera (Nymphaeaceae) rhizome extract. Phytochem. Anal. 2010, 21, 556-560. [CrossRef] [PubMed]

22. Murthy, K.; Mishra, S. TLC Determination of Betulinic Acid from Nymphodies macrospermum: A New Botanical Source for Tagara. Chromatographia 2008, 68, 877. [CrossRef]

23. Bhave, R.K.; Barve, S.S. HPTLC method validation for detection and quantification of betulinic acid in Ancistrocladus heyneanus wall Ex. J. Graham. Int. J. Pharm. Pharm. Sci. 2014, 6, 328-331.

24. Maurya, A.; Srivastava, S. A simple and reliable HPTLC method for the determination of four marker components in the quality control of Alstonia scholaris. JPC TLC 2013, 26, 254-259.

25. Al-Zharani, M.; Nasr, F.A.; Abutaha, N.; Alqahtani, A.S.; Noman, O.M.; Mubarak, M.; Wadaan, M.A. Apoptotic Induction and Anti-Migratory Effects of Rhazya stricta Fruit Extracts on a Human Breast Cancer Cell Line. Molecules 2019, 24, 3968. [CrossRef]

26. Guideline, I.H.T. Validation of analytical procedures: Text and methodology. Q2 (R1) 2005, 1, 1-15.

27. Al-Taweel, A.M.; Perveen, S.; Fawzy, G.A.; Alqasoumi, S.I.; El Tahir, K.E. New flavane gallates isolated from the leaves of Plicosepalus curviflorus and their hypoglycemic activity. Fitoterapia 2012, 83, 1610-1615. [CrossRef]

28. Mariño, G.; Kroemer, G. Mechanisms of apoptotic phosphatidylserine exposure. Cell Res. 2013, 23, 1247-1248. [CrossRef]

29. Wlodkowic, D.; Telford, W.; Skommer, J.; Darzynkiewicz, Z. Apoptosis and beyond: Cytometry in studies of programmed cell death. Methods Cell Biol. 2011, 103, 55-98.

30. Fulda, S. Betulinic Acid for cancer treatment and prevention. Int. J. Mol. Sci. 2008, 9, 1096-1107. [CrossRef]

31. Schmidt, M.L.; Kuzmanoff, K.L.; Ling-Indeck, L.; Pezzuto, J.M. Betulinic acid induces apoptosis in human neuroblastoma cell lines. Eur. J. Cancer 1997, 33, 2007-2010. [CrossRef]

32. Ehrhardt, H.; Fulda, S.; Fuhrer, M.; Debatin, K.M.; Jeremias, I. Betulinic acid-induced apoptosis in leukemia cells. Leukemia 2004, 18, 1406-1412. [CrossRef] [PubMed]

33. Rzeski, W.; Stepulak, A.; Szymanski, M.; Sifringer, M.; Kaczor, J.; Wejksza, K.; Zdzisinska, B.; Kandefer-Szerszen, M. Betulinic acid decreases expression of bcl-2 and cyclin D1, inhibits proliferation, migration and induces apoptosis in cancer cells. Naunyn Schmiedeberg's Arch. Pharm. 2006, 374, 11-20. [CrossRef]

34. Alam, P.; Siddiqui, N.; Al-Rehaily, A.; Alajmi, M.; Basudan, O.; Khan, T. Stability indicating densitometric HPTLC method for quantitative analysis of biomarker naringin in the leaves and stems of Rumex vesicarius $\mathrm{L}$. J. Altern. Complement. Med. 2014, 20, A126. [CrossRef]

35. Alam, P.; Siddiqui, N.A.; Basudan, O.A.; Al-Rehaily, A.; Alqasoumi, S.I.; Abdel-Kader, M.; Donia, A.; Shakeel, F. Comparative profiling of biomarker psoralen in antioxidant active extracts of different species of genus Ficus by validated HPTLC method. Afr. J. Tradit. Complement. Altern. Med. 2015, 12, 57-67. [CrossRef]

36. Alam, P.; Basudan, O.; Siddiqui, N.; Alqasoumi, S.; Abdel-Kader, M.; Raheim Donia Abd El, M.; Alam, P. Development of densitometric HPTLC method for quantitative analysis of biomarker Lupeol in the leaves of different species of genus Ficus. J. Planar Chromatogr. 2015, 28, 30-35. [CrossRef]

37. Siddiqui, N.A.; Alam, P.; Al-Rehaily, A.J.; Al-Oqail, M.M.; Parvez, M.K. Simultaneous quantification of biomarkers bergenin and menisdaurin in the methanol extract of aerial parts of Flueggea virosa by validated HPTLC densitometric method. J. Chromatogr. Sci. 2015, 53, 824-829. [CrossRef]

38. AlAjmi, M.F.; Alam, P.; Siddiqui, N.A.; Basudan, O.A.; Hussain, A. Quantitative analysis of biomarker rutin in different species of genus Ficus by validated NP and RP-HPTLC methods. Pak. J. Pharm. Sci. 2015, 28, 2213-2220.

(C) 2020 by the authors. Licensee MDPI, Basel, Switzerland. This article is an open access article distributed under the terms and conditions of the Creative Commons Attribution (CC BY) license (http://creativecommons.org/licenses/by/4.0/). 